\title{
The Myth of Resurrection: Reimagining Mahabali through the Semiotics of Select Folk Songs
}

\author{
Anitta Anna Moncy \\ Guest Lecturer, Department of English \\ St. Mary's College \\ Manarcaud, Kerala, India \\ anittaanna20@gmail.com
}

Abstract

Written history, being the vehicle of dominant or hegemonic culture, often neglects sub cultural art forms whereas oral or folk culture acts as a reservoir of residual cultural practices. When written history is narrated, unwritten history is sung or performed. The importance of regional folk songs in delineating the subtleties of a particular culture can never be overlooked. Folk songs carry the emotions of the era as well as their associated sociocultural practices.

Mahabali is the central mythical hero of a very prominent traditional festival of Kerala- Onam. Conceptual pluralities in the history of onam festival stand in the way of explaining onam in a unidimensional fashion. Yet, the popular myth goes like this- Mahabali (affectionately called by people as 'Maveli'), the benevolent asura king rules his land in abundance, peace and prosperity, with no instances of theft or murder.

Jealous of King Mahabali's popularity and his power, the Gods conspired to end his reign. They sent Lord Vishnu to earth in the form of a dwarf Brahmin (Vamanan) who trampled Mahabali to the netherworld. But Lord Vishnu granted the king's sole wish i.e. to visit his land and people once every year. This visit is celebrated as onam festival in the Malayalam month of Chingam . 
The just and noble Mahabali in the myth is not just a symbol of peace and prosperity, but a true image of resurrection from oppression, as the history of Kerala would like to tell. Myths and folklore depicts the hope of a generation. This paper tries to probe into the intricacies of the Mahabali myth through select Malayalam folk songs, to bring out the essence of that hope.

Keywords: Onam-Mahabali-Myth-Kerala-Folklore-Folk Songs-Culture-Hegemony-Residual Culture-Resurrection-Oppression-Caste

Onam is not just one among a lot of festivals in Kerala, it's the one thing that all Keralites celebrate, across religions, lands and cultures. Even though it is often argued that onam has achieved its present status as a result of hegemonic cultural transition, the semiotics of the onam myth and its related folk songs can be better connected to the history of the oppressed in Kerala than anything else. The onam myth certainly explains the voyage of culture through various lands and languages, as similar myths of oppression and resurrection can be seen across the world- even in Greek mythology. Basically, onam is a festival related to harvest in Kerala and is celebrated in the Malayalam month of Chingam. The celebration goes on for ten days, as a festival of flowers, colours, songs and food.

"What the world supplies to myth is a historical reality, defined, even if this goes back quite a while, by the way in which men have produced or used it; and what myth gives back in return is a natural image of this reality" says Roland Barthes in_Mythologies_. This is very true in the case of the onam myth. In the tale of Mahabali, Lord Vishnu (in the guise of Vamanan) asks the King three feet of land. When King Mahabali grants the wish, Vamanangrows up to a giant being and measures the whole world with one feet and the heavens with the other. For the third feet, as he had no space left, the benevolent King bows his own head in front of Vamanan to measure and thus the king was pushed to the 
netherworld (hell or pathalam). It is from this netherworld that the King comes to see his people every year, during Chingam.

This is verily a tale of both betrayal and oppression. In feudal Kerala, where the land was owned by the upper caste elites, the situation of the dalits and the low caste was similar to that of the betrayed asura king. Caste hierarchy was internalized by all castes, and all other injustices in the society was in one way or the other, inextricably connected to it. The essential hope of onam is evident in the popular onam song which goes like this:

"Mavelinaaduvaneedumkaalam

Manusharellarumonnupole amodhathodevasikkumkalam apathangarkkumottillathanum kallavumillachathiyumilla ellolamillapolivachanam kallaparayumcherunaazhiyum kallatharangalmattonnumilla adhikalvyadhikalonnumilla balamaranangalkelppanilla dushtarekankondukaanmaanilla nallavarallatheillapaaril vellikolaadikalnaazhikalum ellamkanakkinuthulyamaayi mavelinaduvaneedumkalam manusharellarumonnupole..."

The song can be translated as: 
When Maveli, our King, ruled the land,

All the people were considered equal.

And people were joyful and merry;

They were all free from harm.

There was neither anxiety nor sickness,

Deaths of children were unheard of,

There were no lies,

Cruel people were not to be seen,

Everyone was good in the world,

There was neither theft nor deceit,

And no one was false in speech either.

Measures and weights were right;

No one cheated or wronged his neighbor.

When Maveli, our King, ruled the land,

All the people formed one casteless race.

The lack of cruelties mentioned in the song were the result of a casteless society, caste system being the root of all evils and the greatest injustice of Kerala society. The picture of Mahabali that we receive from the song is that of a just and noble king, who believed in equity and socialism. The land was devoid of all sorts of corruption, under his rule. He proposed and made a welfare state, an ideal state in all the utopian narratives around the world. This harmony, peace and welfare of all people, irrespective of caste or creed, created envy among the Gods, according to the myth. It is a clear indication that the society believed that an idea welfare state would threaten a hegemonic class always and would ultimately result in the end of their privileges, be it Gods or humans. 
Persistent sickness or even sadness was seen as a result of an unequal social order. During the reign of Mahabali, people were devoid of both sickness and sadness because their physical, emotional and economic welfare was taken care of under his Kingdom. When religions around the world preach about a crime free society, they fail to notice the root of major social crimes- either poverty or greed. Both were absent under Mahabali's reign. It's not just that people did not steal, they never had to do so. That is the key of this dream like myth.

Sahodarn Ayyappan, the famous discipline of Sree Narayana guru, added more lines to the above said onam song, making it a clear depiction of the real dream of renaissance Kerala and its connection with the onam myth. The added lines are:

Theendalumillathodeelumilla Vendatheenangalmattonnumilla

Chorukalvachullapoojayilla

Jeeviyekollunnayagamilla

Dallaalvazhikeeshasevayilla

Vallathadeivangalonnumilla

Saadhudhanikavibhagamilla

Mooladhanathinnjerukkamilla

Aavathavaravarcheithunaattil

Bhoothivalarthanjanamsramichu

Vidyapadikkanvazhiyevarkkum

Sidhichumabalivazhumkalam

Sthreekumpurushanumthulyamayi

Vachuswathanthrathaenthubhagyam

Kaalikkukoodichikilsacheyyan 
Aalayamsthapichithannumarthyar

Saugatharevamparishkritharaayi

Sarvamjayichubharichuponnor

Brahmanarkeershyavalarnnuvanni

Bhoothikedukkanavarthuninju

Kaushalamarnnoruvamanane

Vittuchathichavarmabaliye

Daanamkoduthasumathithante

Sheershamchavittiyaayachakanum

Annuthottindhyaadhapathichu

Manniladharmamsthalamnirachu

Dhallalmathangalniranjukashtam

Kollunnakrooramathavumethi

Varna vibhagavyavasthavannu

Mannidamthannenarakamakki

Marthyanemarthyanashudhanaakkum

Ayithapishachumkadannukeri

Thannilashakthantemelilkeri

Thannilbalishtantekaaluthangum

Snehavumnaanavumkettareethi

Maanavarkkekamamdharmamaayi.

Sadhu janathinviyarppunjekki

Nakkikudichumadiyarveerthu

Nandiyumdeenakarunathanum

Thinnukozhuthivarkkethumilla 
Sadhukkalaksharamcholliyenkil

Garvishtareedushtarnakkaruthu

Sthreekalivarkkukalippanulla

Paavakalennuvaruthivachu

Aandhyamasooyayummoothuparam -

Swanthabalam poi janangalellam

Kashtamekashtampurathuninnu-

methiyorkokeadimappettu

Ethranoottandukalnammalevam

Budhimuttunnusahodarare

Nammeuyarthuvannammalella

monnichunarenamkelkkaningal

Brahmanopajnjamamkettamatham

Sevippavarechavittummatham

Nammalethammilakattummatham

Nammalvediyenamnanmavaran

Sathyavumdharmavummathramallo

Sidhivaruthunnashudhamatham

Dhyanathinaleprabudharaaya

Divyaraalnirdhishtamaayamatham

Aamathathinaalsramichidenam

Aamathathinunaamchathidenam

Vaamanaadarshamvedinjidenam

Mabalivazhchavaruthidenam

Onam namukkininithyamenkil 


\section{Oonamvaratheirunnukollum.}

Translation of the lines :

There is no untouchability

There are no other disadvantages

No pooja with chorus -

There is no living sacrifice

There is no cash service through a broker

There are no bad gods

No valid category of rich or poor

There is no shortage of capital

Everyone did what they could -

People tried to raise the fame of the land

Everyone had a way towards education

When Mabali ruled the land

Women and men alike

Enjoyed their freedom

Shelters for treatment of cattle

Were built by humans

Everyone became civilized

Brahmins became offended

They tried to disrupt the fame of the land

They sent the cunning Vamana

and cheated Mabali

The head of the benevolent doner was trampled by the vagrant

From that day onwards 
India became degraded

Injustice bagan to rule the land

Broker religions took over

The cruel religion of killing arrived

The caste system came -

and made the land hell

The demon of untouchability

That makes man impure to man came into being.

The loveless and shameless practice of appeasing the powerful

by oppressing the powerless

became the unique of mankind

The lazy flourished by

drinking the sweat of the poor

Such gluttons have no

Love or compassion

If the poor learned or uttered letters

the proud cruel men chopped their tongue

They made women their playthings

Jealousy and hatred grew

And people lost self worth

Alas! Foreigners took over the land and enslaved the people

How many centuries should we

live in chains, brothers?

To lift us up we should

Arise and awake together $\mathrm{O}$ 
Brahmanism is a bad religion

Which tramples on those who serve

And which divides us- we should leave it

Truth and justice is the only

Pure religion that brings prosperity

Religion prescribed by those who

Are enlightened by meditation

We should strive for that religion

We must die for that religion

Vamana's ideal should be abandoned

Mabali should rule

If Onam is eternal for us

No disaster will befall us.

The addition made by Sahodaran Ayyappan amply contracts the ideal and mythical kingdom of Mahabali with the injustices of feudal Kerala.Misogynist and casteist practices which were the product of brahminism resulted in weakening of India in general and Kerala as a society and thus foreign powers were able of overpower a divided set of people. During the reign of Mahabali, all kinds of discriminations based on wealth, gender, caste and power were absent. The jealousy of the Gods towards this ideal kingdom can be related to the commonly held belief that caste hierarchy is 'God given' and therefore should be considered as having sanctity, to be followed without fail. In the song division of caste among the people of India and the resultant weakening of India as a nation is considered as the real reason behind colonization of India.

Not just humans, but animals too benefitted from the reign of Mahabali. They were not used for religious sacrifices, and hospitals were built up for their treatment. Right to 
education, which was the monopoly of the brahmins, was provided to everyone. According to the narrative of the song, this kind of an egalitarian social system based on equity, socialism and justice goaded the Gods to take revenge. They felt like losing their power. It is debatable whether Vamananis a hegemonic or brahminical symbol who tried to oppress the benevolent asura king. The truth is that myth always saves space for the unexplainable to have divine nature and qualities. Brahminism and casteism, as cruel as it is, comes in the form of 'sweet revenge' of the Gods for surpassing their powers. In fact, it is the base assumption that the hierarchical injustices are natural or God given.

The song powerfully portrays the role of religion in promoting an unjust and unequal society. Both the religion of the land (Hinduism) and the foreign religions which came as a result of colonization, were equally supportive of caste hierarchy and oppression of women. The only religions worth treasuring, propagating and dying for are truth and justice. Only those religions bring prosperity to the land as did Maveli's reign, according to the song. When caste, which is a hierarchical form of graded inequality enslaved the people, colonial powers took over the land and enslaved the people as a whole. Even after this, the people didn't save themselves from the devil of caste. People should renounce all kinds of religions which promote caste and embrace truth and justice to bring freedom and welfare to the nation, or in other words, to bring back the ideal land of Mahabali.

Pakkanarpattu is a genre of folk songs of Paraya community in Kerala. In one of these songs, the return of Mahabali, its cause and the arrangements for receiving him are mentioned in detail.

\section{Aayiramkathamvadakkuninnu}

VaravathundenteMaveliyaam

Manusharudevazhichakanan 
Maveliyamvaravathunde

Maveliyamvarumvazhikk

Enthunallavarthamanam

Manjanallamunduvenam

Mandirakodivenam

Kakkapanamkathirvilakk

Adukkalakkakatherika

Thookumanamthudarvilakk

Adukkalakkpuratherika

Translation of the song:

From thousand miles north

Comes Maveli

To see the life of humans

Comes Maveli

It's a great news-

That Maveli comes

We need yellow waistcloth

And blessed new cloth

Crow coin and lantern

Should light inside kitchen

Hangings and lamps

Should light outside kitchen 
Newness and freshness is in the air when Onam comes. The lights and golden clothes mentioned in the song symbolize the joy of the occasion. As exciting as onam is to the people who hope for an egalitarian land, the story of jealousy betrayal of Gods towards the benevolent King is never forgotten. In one of the Pulluvappattu - folk songs of Pulluva castewe can see this:

\section{"Pandu Mahabalidharithrithannil}

Vashamaakkibrahmanadithadharal

Ancharkontenilayummudangi

yazhakoduvaanuchirakalavum

\section{Onamennakadhakelkkanam}

Sakalalokavumtharunivrindavum"

Translation:

Long ago Mahabali was tricked

by elite Brahmin Gods

He lost his positions and

lived the rest of his life like that

The story of Onam

Should be heard by

Men and women

Around the world.

The song itself says that the real story of onam, in all its purity- including the story of betrayal of Gods and resurrection of Mahabali should be popularized all over the world. It 
seems as if the the myth and all the songs and stories related to it have something to remind humanity. The mythical hero goes amidst the people and gradually becomes one of them. People empathize with the tragic hero all through the tale and waits for his return to celebrate their prosperity with him. This is how the onam myth transcends temporal and spatial boundaries and becomes a universal narrative of rebirth and rejuvenation.

All these remembrances and songs have an inevitable position in the history of Kerala. In the myth, the asura King's benevolence is juxtaposed with the jealousy and hatred of the Gods. Likewise, caste hierarchy based on brahminism has ostracized not just the lives of the dalits, but the subcultural art forms as well. All the unwritten folk songs are relics of the powerful lives of people who were pushed out to the peripherals of the society. In other words, they cater to the 'collective unconscious' of the people, reminding them of their history through stories and their land's soul through songs.

In Kerala, onam is celebrated as a harvest festival. Around the world, harvest is the time of embracing the romantic collection of mythology. What people believe to bring prosperity and happiness will be cherished at this time of the year. Onam brings the joy of celebration in the minds of people after the month of famine called Karkidakam in Malayalam. It comes in between July and August. The month after Karkidakam is called Chingam (from mid August to mid September) in which onam is celebrated. There is a famous adage in Malayalam - "KallaKarkidakampopo, ponninChingamvava" which means "let the miserable Karkidakam go and let the golden Chingam come". This saying speaks not just about the famine of Karkidakam or the rainy season, but the wait for onam for an entire year, of an agrarian society.

What mass culture and consumer capitalism have done to the onam narrative is that they have homogenized onam to a celebaration of new material goods and clothes. Now onam has become just a celebration or a vacation and it is high time the real hope of onam is 
reminded to the people. If the universality of justice, envy, betrayal and resurrection is what makes onam a universal saga, what makes it a tale of hope is the unique engineering of a socialist and egalitarian society by the mythical hero.

Onam is a hope of the rise of the historically befooled and systemically oppressed. It is the hope for the liberation of dalits, women and all sorts of oppressed categories of people. The spirit of onam as projected by the mass media- fair skinned ladies preparing vegetable dishes and people wearing new golden clothes chanting and swinging- is an image apt for a consumer capitalist social order. On the other hand, the real soul of onam as we see in the dying folk songs and other bygone subcultural art forms paint before us the hope of generations of people in Kerala. The parallelism between the Maveli myth and feudal Kerala society is not just a flowery romantic metaphor. It juxtaposes art and life, in the most sublime manner and amazes us by showing how in the peripherals of hegemonic art forms lie the residual art forms in which the soul of generation are engraved. As the folk songs eloquently tell us, onam isn't just a myth- it is a hope- a hope of resurrection. 


\section{Works Cited}

H Kuriakose\& E Soreng (2020). Myth of Vamana and Mahabali: Jungian approach to the origin of Onam festival. International Journal of Indian Psychology, 8(2), 912-919. Michael, James: "The Murder of Dalit-Bahujan King Mahabali and the Myth of Onam", Round Table India, 26 August 2012.

Nagarajan, Saraswathy. "How Kerala is on song during Onam." Thehindu, 29 Aug.2020, https://www.thehindu.com/entertainment/music/malayalam-songs-that-evoke-onamin-every-keralite/article32466246.ece

Pande, Mrinal. "Vamana and Onam: The tale of Mahabali that began it all." Scroll, 14 Sep.2016, http://scroll.in/article/816513/vamana-and-onam-the-tale-of-mahabali-thatbegan-it-all

Sekher, Ajay. S. "The Legend of Mahabali — An Egalitarian Buddhist King." myftpupload, 10 Sep. 2019, http://qjk.9bc.myftpupload.com/2019/09/10/the-legend-of-mahabali-anegalitarian-buddhist-king/ 